\title{
Epidemiology of domestic cat behavioral problems in the city of Porto Alegre/Brazil: a survey of small animal veterinary practitioners
}

\author{
Nathalia Saraiva de Albuquerque ${ }^{*}$ (iD Guilherme Marques Soares ${ }^{2}$ \\ ${ }^{1}$ Médica Veterinária Autônoma, 91770-560, Porto Alegre, RS, Brasil. E-mail: nathydealbuquerque@outlook.com. "Corresponding author. \\ ${ }^{2}$ Universidade Severino Sombra (USS), Vassouras, RJ, Brasil.
}

ABSTRACT: The popularity of cats as a companion animal has been growing. Additionally, there is also an increase in the number of complaints regarding behavioral problems associated with the species. Behavioral problems interfere with the animal welfare and quality of people's lives that are living with them, and are one of the main reasons for abandonment and euthanasia in some countries. This study aimed to investigate the prevalence of behavioral problems among cats with the help of veterinary practitioners in the city of Porto Alegrel Brazil. This evaluation was performed through a questionnaire in veterinary clinics and hospitals of small animals, which was answered by veterinarians responsible for clinical care. The study showed that most veterinarians $(92.0 \%)$ have been sought to assist with behavioral problems and that dogs were the most consulted species (72.0\%). Regarding cats, scratching was the most common owners' complaints $(40.0 \%)$, followed by aggressiveness $(39.0 \%)$, and inappropriate elimination of urine (38.0\%). Aggression (73.8\%) and scratching (56.9\%) were the most frequent reasons that may lead to the abandonment or euthanasia of cats. Results of this research highlighted the importance of having a better understanding about the normal behavior of cats, and the fundamental role of the veterinarian in preventing behavioral problems and abandonment of these animals.

Key words: epidemiology, animal welfare, animal behavior, behavior problems, cats.

Epidemiologia de problemas comportamentais de gatos domésticos no município de Porto Alegre: inquérito entre médicos veterinários de pequenos animais

RESUMO: A popularidade do gato como animal de companhia vem crescendo, e junto com esse crescente número de gatos, crescem também as queixas de problemas comportamentais dessa espécie. Os problemas de comportamento comprometem o bem-estar dos animais e a qualidade de vida das pessoas que com eles convivem, sendo uma das principais causas de abandono e eutanásia de gatos em alguns países. O objetivo do presente estudo foi avaliar a prevalência dos problemas comportamentais em gatos atendidos pelos médicos veterinários no município de Porto Alegre, RS. Essa avaliação foi feita através de um questionário aplicado em consultórios, clínicas e hospitais veterinários de pequenos animais, para serem respondidos pelos médicos veterinários responsáveis pelo atendimento clínico. Dos 100 questionários respondidos pelos médicos veterinários, 92,0\% afirmam que são consultados sobre problemas de comportamento e 72,0\% responderam que o cão era a espécie mais consultada. No que se refere aos problemas comportamentais especificos dos gatos, a arranhadura foi a queixa comportamental mais comum citada pelos médicos veterinários (40,0\%), seguida de agressividade (39,0\%) e eliminação inapropriada com urina $(38,0 \%)$. A agressividade $(73,8 \%)$ e a arranhadura $(56,9 \%)$ foram citadas como as mais frequentes razões que podem levar ao abandono ou eutanásia dos gatos. Os resultados dessa pesquisa destacam a importância de haver maior conhecimento sobre o comportamento normal do gato, e o papel fundamental do médico veterinário clinico na prevenção de problemas comportamentais e no abandono desses animais. Palavras-chave: epidemiologia, bem-estar animal, comportamento animal, problemas comportamentais, gatos.

\section{INTRODUCTION}

The number of people interested in having a cat as an animal companion has been increasing, and this growth in the population of cats is because people believe that cats can adapt better than dogs to the circumstances offered (GENARO, 2013). They can live easily in a restricted environment, do not need to be taken out, and are more tolerant about spending prolonged periods alone (MENGOLI et al., 2013). In recent times, as people have less time and space, the cat has become a preferred animal companion. However, without the knowledge of the cats' behavioral needs, this can lead to conflict situations between the owner and his cat (GENARO, 2013).

Although, cats are the most popular pet in the United States (VOGT et al., 2010), euthanasia due to behavioral problems is the main cause of death of cats in 
the country (RODAN \& HEATH, 2016). The majority of these animals initially had an owner, and were abandoned in some moment in their life (GENARO, 2013). Many of these abandonments were due to behavioral problems, including normal cat behavior, which owners find undesirable (RODAN \& HEATH, 2016).

Therefore, the veterinarian in such situations should inform the animal's owner about the behavioral characteristics of cat species and discuss what to expect of a cat as a companion animal. This reduces the possibility of a conflict and enhances the relationship between the cats and their owners (GENARO, 2013).

Prevention and early diagnosis are much more efficient to correct behavioral disorders (DANTAS et al., 2009). Therefore, the goal of this study was to identify the most frequent behavioral problems attended by veterinarians in the city of Porto Alegre, Brazil, and the consequences of these problems on animal welfare and the relationship between people and their cats.

\section{MATERIALS AND METHODS}

The questionnaire used to collect the data was adapted from that used by FATJÓ et al. (2006); the questions ranged from asking a veterinarian's attitude when facing a behavioral problem, to asking for an estimate of the most frequent behavioral problems observed by veterinarians and the general methods used to treat them (Figure 1). Questions 1 and 2 obtained data for both dogs and cats. Questions 3 to 8 were specific for cats. The questionnaire was applied personally by the researcher to small-animal veterinary

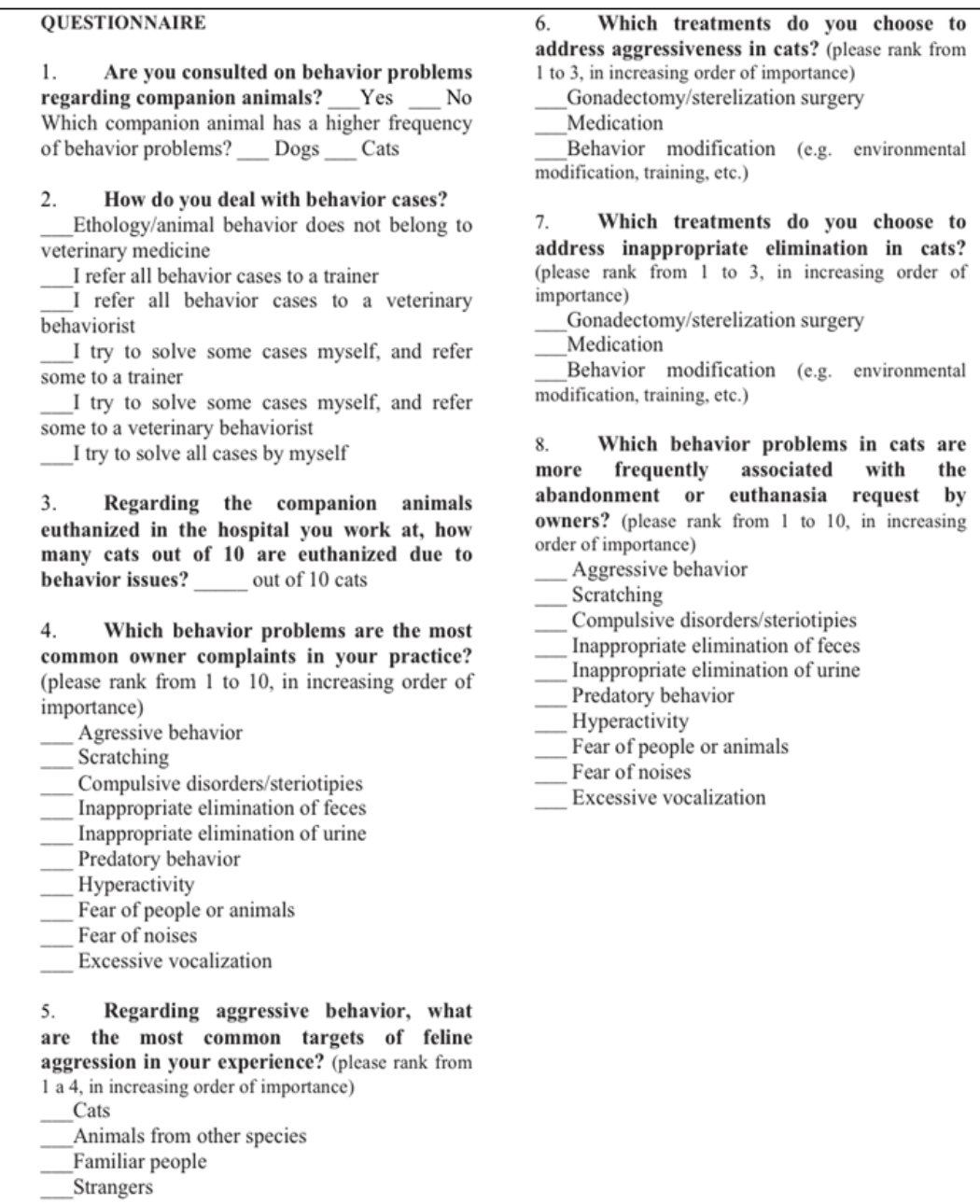

Figure 1- Questionnaire used to collect the data, which was adapted from the questionnaire of FATJÓ et al. (2006) and applied in an epidemiological survey conducted with veterinarians in Porto Alegre-Brazil, 2018. 
practices in Porto Alegre. In total, 127 veterinary practices were invited to participate in the research.

The questionnaire was answered at the time of the researcher's visit or left in the establishment for a week to be answered; those who did not fill the questionnaire within the time frame were excluded from the survey. Another criterion for exclusion from the study was that the veterinarian was not a resident of Porto Alegre or did not attend cats.

The answers obtained were stored in a Microsoft Office Access $2007^{\circledR}$ application database and analyzed via non-parametric tests using the Bioestat $^{\circledR} 5.3$ program. Responses to questions $1-3$ were analyzed descriptively, and those to questions 4-8 were analyzed using the Kruskal-Wallis and Student-Newman-Keuls tests.

\section{RESULTS AND DISCUSSION}

According to the information provided by CRMV-RS, 2,260 veterinarians working in the city of Porto Alegre, of which 127 veterinarians were invited to participate in the study and 100 responded to the questionnaire; the response rate was thus $78.0 \%$. The city of Porto Alegre is divided into 8 regions, which were represented as follows: central region, 44 questionnaires (44.0\%); south zone, 22 questionnaires $(22.0 \%)$; north zone, 21 questionnaires $(21.0 \%)$; east zone, 5 questionnaires $(5.0 \%)$; region of glória and cristal, 4 questionnaires (4.0\%); region of partenon and agronomia, 3 questionnaires (3.0\%); and northeast zone, 1 questionnaire $(1.0 \%)$. The region that corresponds to the extreme south zone of Porto Alegre was not represented in this study.

Of the 100 responses, $92.0 \%$ veterinarians confirmed that they were consulted about behavioral problems. The species accounting for most of these consultations was dogs for $72.0 \%$, cats for $11.0 \%$, and both dogs and cats for $10.0 \%$. Although, the majority of veterinarians are consulted about behavioral problems, no specific data were available for the number of cases. These results correspond to those reported by studies from other countries (FATJÓ et al., 2006) and also those obtained by DANTAS et al. (2009), who carried out a similar study in the animal hospitals associated with the university in Brazil, demonstrating that behavioral issues constituted a part of veterinary practitioners' routine in Brazil. The fact that the dogs are the species accounting for the most consultations may be related to the lower number of cats than of dogs being taken to veterinarians; this is mostly because owners want to avoid stress or fear for the cats associated with veterinary visits and prefer to avoid visits as much as possible (VOGT et al., 2010).
According to the veterinarians, $51.0 \%$ try to solve some behavioral problems by themselves, but they also refer some patients to veterinary behaviorists; $36.0 \%$ try to solve part of the behavioral cases by themselves and partially refer to trainers; and $8.0 \%$ referred all patients with behavioral issues to veterinary behaviorists. Only $4.0 \%$ mentioned that they try to solve all cases by themselves, and $1.0 \%$ mentioned referring all patients to trainers. None of the veterinarians reported that ethology was not a veterinary field. In this survey, trainers refer to people who may or may not be a graduate in veterinary medicine and teach obedience commands for dogs. In the present study, the majority of respondents declared that they refer some patients to veterinary behaviorists, which shows that there are professionals specialized in animal behavior in Porto Alegre; although, there are no data about the percentage of veterinaries consulted for cat behavioral problems. These results are consistent with the results of other studies regarding the same issue in Brazil (DANTAS et al., 2009). Other countries that address this issue have obtained different results: a survey conducted in Spain showed that more than 35.0\% practitioners never referred cases, neither to veterinary behaviorists nor to trainers. The same survey explains this approach claiming a lack of communication between the specialist and the practitioner, or because many practitioners still cannot recognize behavioral problems, or they do not accept ethology as a veterinary field (FATJÓ et al., 2006). Although, in the present study, there was no answer suggesting that ethology was not part of veterinary medicine, the same approach as mentioned above may be present among practitioners in Porto Alegre, because only $8.0 \%$ mentioned that they referred all patients with behavioral issues to a specialist. However, another hypothesis for this low percentage is the small number of behaviorists, making it difficult to refer the patient (DANTAS et al., 2009).

When the veterinarians were asked if they euthanized cats because of behavioral problems, all of them denied following this practice. However, this result contrasts with international literature where $75.0 \%$ of professionals have estimated that at least $10.0 \%$ of the euthanasia performed is for behavioral problems (FATJÓ et al., 2006). As per the results of this study, cats are not euthanized on the basis of behavioral problems in Brazil, and it is more common for owners to abandon cats with such problems on the streets instead of requesting euthanasia from a veterinarian (DANTAS et al., 2009).

Regarding the question about complaints from cat owners, scratching was the most frequent complaint $(40.0 \%)$, followed by aggressiveness (38.0\%) and inappropriate elimination of urine (38.0\%) (Table 1, Figure 2). The Kruskal-Wallis test showed 
Table 1- The ranking from 1 to 10 in increasing order of importance, and the number of respondents for the most common behavioral problems reported in an epidemiological survey conducted with veterinarians in Porto Alegre-Brazil, 2018.

\begin{tabular}{|c|c|c|c|c|}
\hline \multicolumn{2}{|c|}{ Behavioral problems } & \multicolumn{3}{|c|}{ 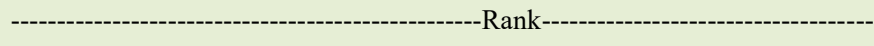 } \\
\hline & & $1-4$ & $5-7$ & $8-10$ \\
\hline 1. & Aggressiveness & $\mathrm{n}=35(35.0 \%)$ & $\mathrm{n}=27(27.0 \%)$ & $\mathrm{n}=38(38.0 \%)$ \\
\hline 2. & Scratching & $\mathrm{n}=31(31.0 \%)$ & $\mathrm{n}=29(29.0 \%)$ & $\mathrm{n}=40(40.0 \%)$ \\
\hline 3. & Compulsive disorders & $\mathrm{n}=41(41.0 \%)$ & $\mathrm{n}=29(29.0 \%)$ & $\mathrm{n}=30(30.0 \%)$ \\
\hline 4. & Predatory behavior & $\mathrm{n}=72(72.0 \%)$ & $\mathrm{n}=18(18.0 \%)$ & $\mathrm{n}=10(10.0 \%)$ \\
\hline 5. & Inappropriate elimination of feces & $\mathrm{n}=51(51.0 \%)$ & $\mathrm{n}=32(32.0 \%)$ & $\mathrm{n}=17(17.0 \%)$ \\
\hline 6. & Inappropriate elimination of urine & $\mathrm{n}=28(28.0 \%)$ & $\mathrm{n}=34(34.0 \%)$ & $\mathrm{n}=38(38.0 \%)$ \\
\hline 7. & Hyperactivity & $\mathrm{n}=60(60.0 \%)$ & $\mathrm{n}=31(31.0 \%)$ & $\mathrm{n}=09(09.0 \%)$ \\
\hline 8. & Fear of people or animals & $\mathrm{n}=44(44.0 \%)$ & $\mathrm{n}=32(32.0 \%)$ & $\mathrm{n}=24(24.0 \%)$ \\
\hline 9. & Fear of noises & $\mathrm{n}=52(52.0 \%)$ & $\mathrm{n}=35(35.0 \%)$ & $\mathrm{n}=13(13.0 \%)$ \\
\hline 10. & Excessive vocalization & $\mathrm{n}=50(50.0 \%)$ & $\mathrm{n}=36(36.0 \%)$ & $\mathrm{n}=14(14.0 \%)$ \\
\hline
\end{tabular}

significant differences among items $(\mathrm{P}<0.0001)$. Pairwise comparison (Figure 3 ) for aggressiveness and scratching showed no significant differences. When compared with inappropriate elimination of urine, both aggressiveness and scratching showed no significant differences. Results obtained in this study are in agreement with those obtained in a study carried out in a veterinary hospital in Porto Alegre, where scratching was also cited as the most frequent behavioral problem (61.3\%), followed by aggressiveness (45.3\%) and inappropriate elimination of urine (38.6\%) (PAZ et al., 2017). In a study conducted in Spain, aggressiveness (47.0\%) and inappropriate elimination $(39.0 \%)$ were also reported to be the main complaints of cat owners (AMAT et al., 2009). However, DANTAS et al. (2009) reported the most common complaint of cat owners to be inappropriate elimination of urine (34.8\%), followed by scratching (28.3\%). Scratching has been reported to be the second most frequent complaint in others countries (FATJÓ et al., 2006; WILSON et al., 2015). This may be because most people are unaware that scratching is a normal behavior of cats and do not provide adequate conditions for cats to scratch. According to the study by PAZ et al. (2017), cats with designated areas for scratching had a $69.0 \%$ less risk of scratching in unwanted places. The results of these

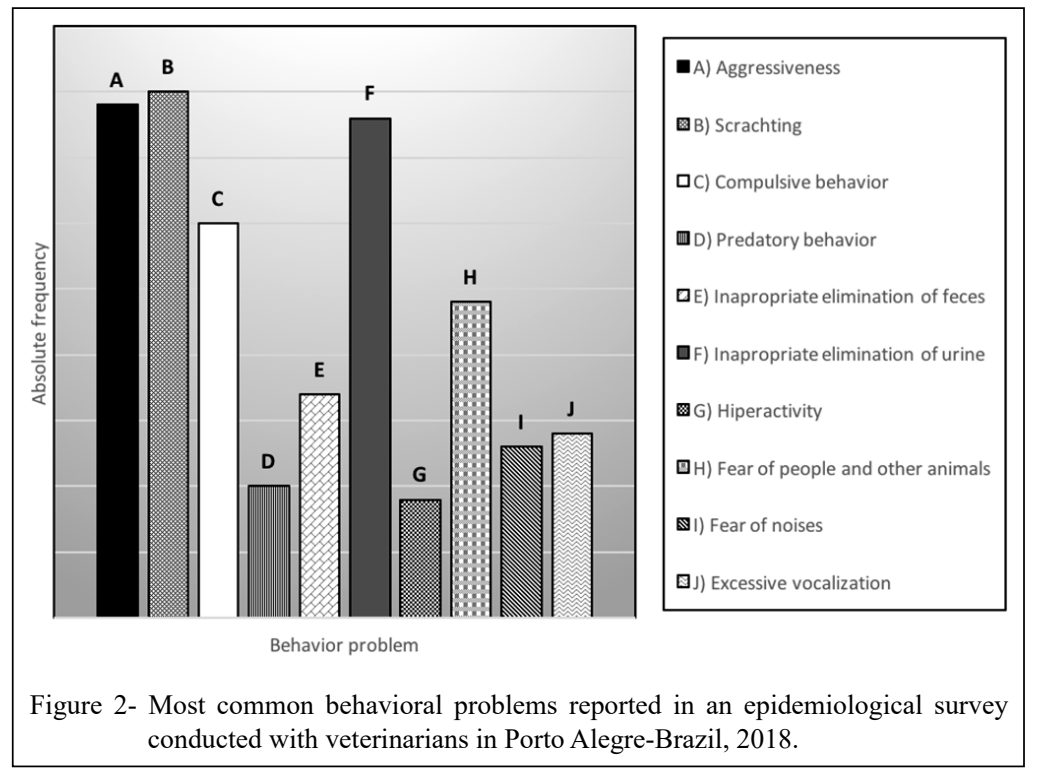

Ciência Rural, v.49, n.10, 2019. 


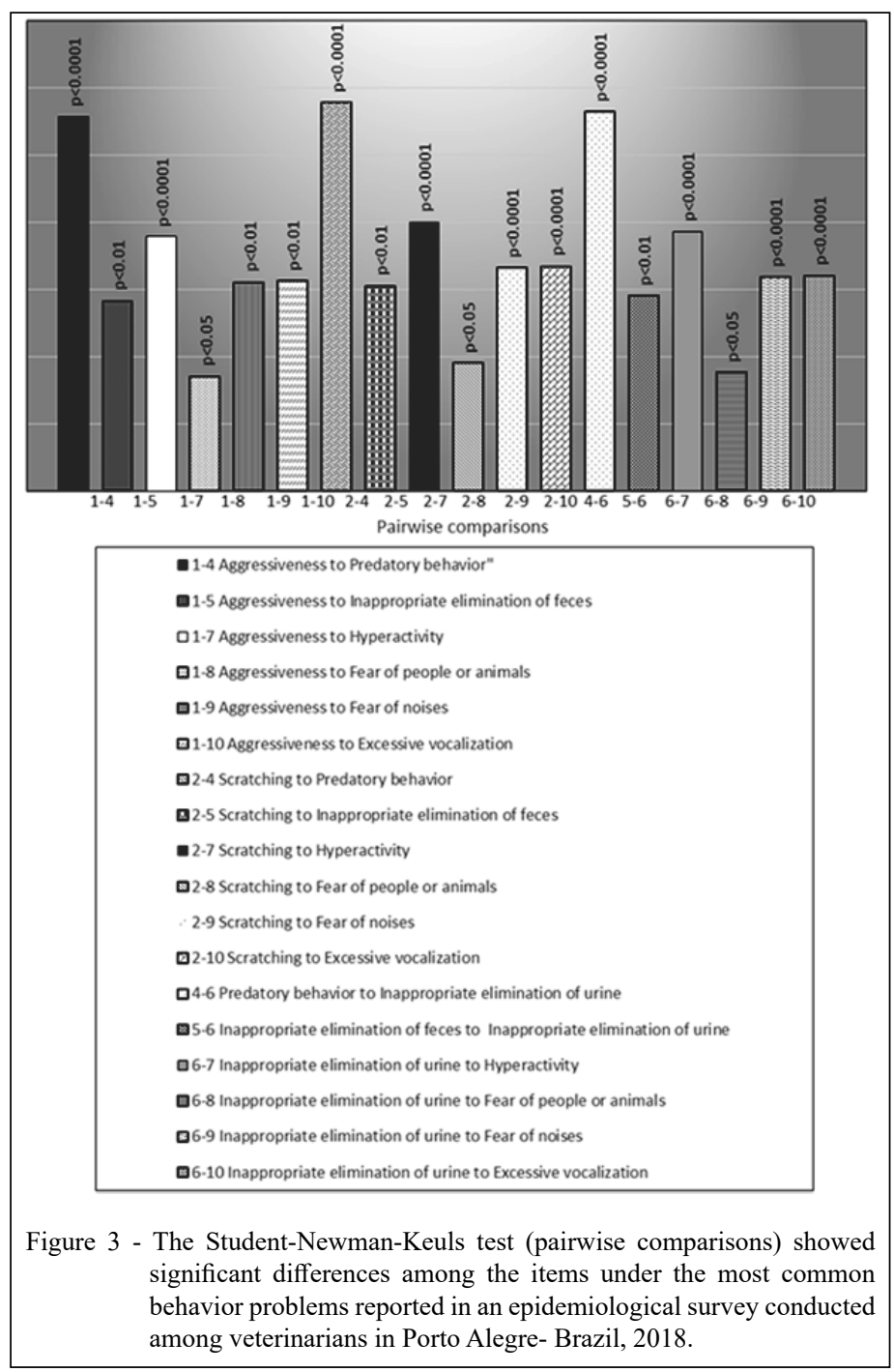

surveys affirm the need for veterinarians to advise owners to provide a scratching post for scratching behavior (WILSON et al., 2015).

In the present study, aggressiveness was the second most common complaint, which is a serious concern, since aggression towards people might affect not only the welfare of the cat, but also the pet-owner relationship, in addition to having public health implications, due to the risk of zoonoses (RAMOS \& MILLS, 2009).

Inappropriate elimination of urine is also one of the main complaints of cat owners; however, in order to simplify data collection and interpretation, spraying was grouped together with inappropriate elimination in this survey. Spraying is a marking behavior with the intent of communication (HORWITZ \& MILLS, 2009), and inappropriate elimination per se, is the failure to use the litter box (DANTAS et al., 2009). Our result agreed with the data obtained from surveys in other countries (FATJÓ et al., 2006), where inappropriate elimination of urine is among the three main concerns of cat owners, highlighting the importance of veterinarians being able to distinguish between medical and behavioral causes of inappropriate elimination of urine (SCARLETT et al., 2002).

When questioned about behavioral issues that motivate a request for euthanasia or relinquishment of cats by owners, $41.0 \%$ veterinarians did not respond, claiming to have never been in such a situation. The questionnaires that were responded to reveal that aggressiveness was the most common complaint associated with relinquishment or request for euthanasia $(73.8 \%$, Table 2, Figure 4). 
Table 2 - The ranking from 1 to 10 in increasing order of importance, and the number of respondents for the most frequent behavioral problems associated with abandonment or euthanasia of domestic cats, according to an epidemiological survey conducted with veterinarians in Porto Alegre-Brazil, 2018.

\begin{tabular}{|c|c|c|c|c|}
\hline \multicolumn{2}{|c|}{ Behavioral problem } & \multirow{2}{*}{$1-4$} & \multirow{2}{*}{$5-7$} & \multirow{2}{*}{$8-10$} \\
\hline & & & & \\
\hline 1. & Aggressiveness & $\mathrm{n}=10(15.4 \%)$ & $\mathrm{n}=7(10.8 \%)$ & $\mathrm{n}=48(73.8 \%)$ \\
\hline 2. & Scratching & $\mathrm{n}=17(26.1 \%)$ & $\mathrm{n}=11(16.9 \%)$ & $\mathrm{n}=37(56.9 \%)$ \\
\hline 3. & Compulsive disorders & $\mathrm{n}=36(55.3 \%)$ & $\mathrm{n}=21(32.3 \%)$ & $\mathrm{n}=08(12.3 \%)$ \\
\hline 4. & Predatory behavior & $\mathrm{n}=43(66.1 \%)$ & $\mathrm{n}=12(18.5 \%)$ & $\mathrm{n}=10(15.4 \%)$ \\
\hline 5. & Inappropriate elimination of feces & $n=29(44.6 \%)$ & $\mathrm{n}=24(36.9 \%)$ & $\mathrm{n}=12(18.5 \%)$ \\
\hline 6. & Inappropriate elimination of urine & $\mathrm{n}=24(36.9 \%)$ & $\mathrm{n}=20(30.8 \%)$ & $\mathrm{n}=21(32.3 \%)$ \\
\hline 7. & Hyperactivity & $\mathrm{n}=41(63.1 \%)$ & $\mathrm{n}=21(32.3 \%)$ & $n=03(04.6 \%)$ \\
\hline 8. & Fear of people or animals & $\mathrm{n}=58(89.2 \%)$ & $\mathrm{n}=07(10.8 \%)$ & $\mathrm{n}=0$ \\
\hline 9. & Fear of noises & $\mathrm{n}=62(95.4 \%)$ & $\mathrm{n}=03(04.6 \%)$ & $\mathrm{n}=0$ \\
\hline 10. & Excessive vocalization & $\mathrm{n}=37(56.9 \%)$ & $\mathrm{n}=20(30.8 \%)$ & $\mathrm{n}=08(12.3 \%)$ \\
\hline
\end{tabular}

Scratching was the next most common issue (56.9\%). Fear of people or other animals and fear of noises were not listed among the main reasons for euthanization or relinquishment of cats. The Kruskal-Wallis test showed significant differences among items $(\mathrm{P}<0.0001)$. Pairwise comparison (Figure 5), showed no significant differences in aggressiveness compared to other problems. These results agree with the results found by DANTAS et al. (2009), wherein aggressive behavior was also the most common problem, but are in contrast with the results of SALMAN et al. (2000), where inappropriate elimination was the most frequent complaint leading to euthanasia or relinquishment of dogs and cats in the United States. Behavioral problems are one of the main causes leading to the abandonment of dogs and cats. About $28.0 \%$ of cats abandoned in shelters in the United States had one or more behavioral problems, which was one of the reasons that lead to their abandonment (SALMAN et al., 2000). The high proportion of veterinarians who refused to answer this question indicated that, in Porto Alegre, owners do not seek help from a veterinarian before abandoning their cats. Therefore, veterinary practitioners need to understand the main reasons behind owners abandoning

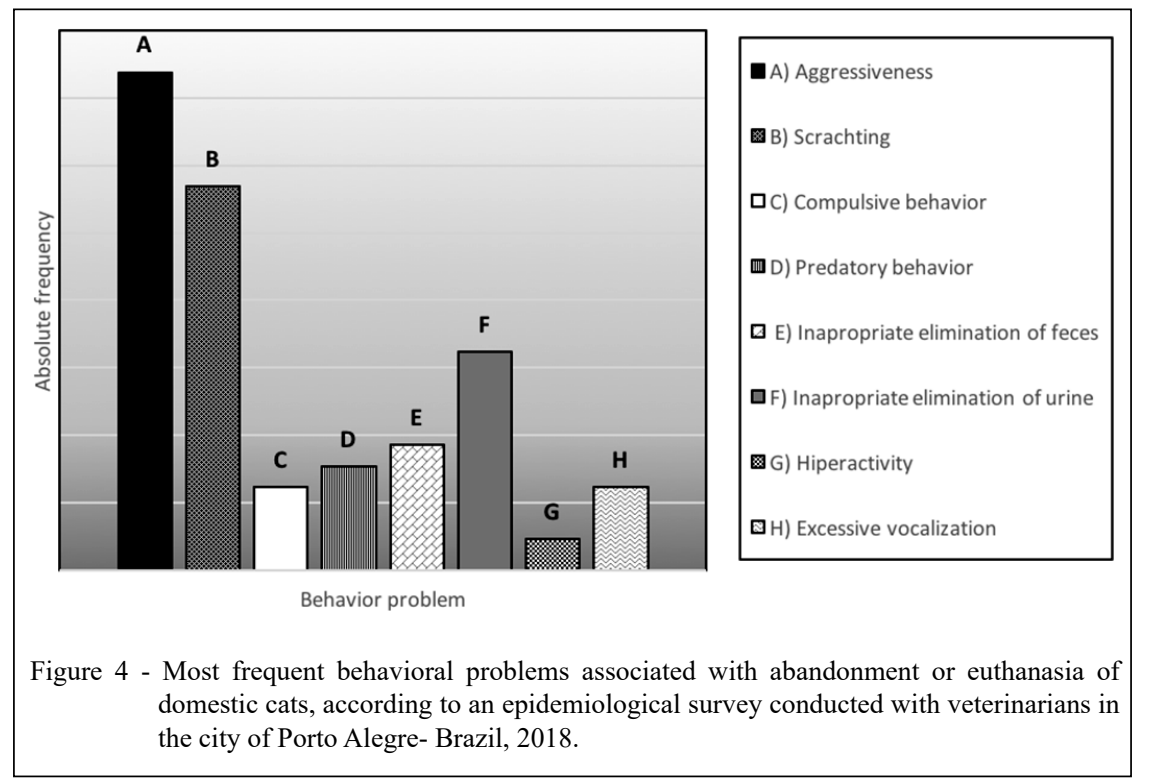

Ciência Rural, v.49, n.10, 2019. 


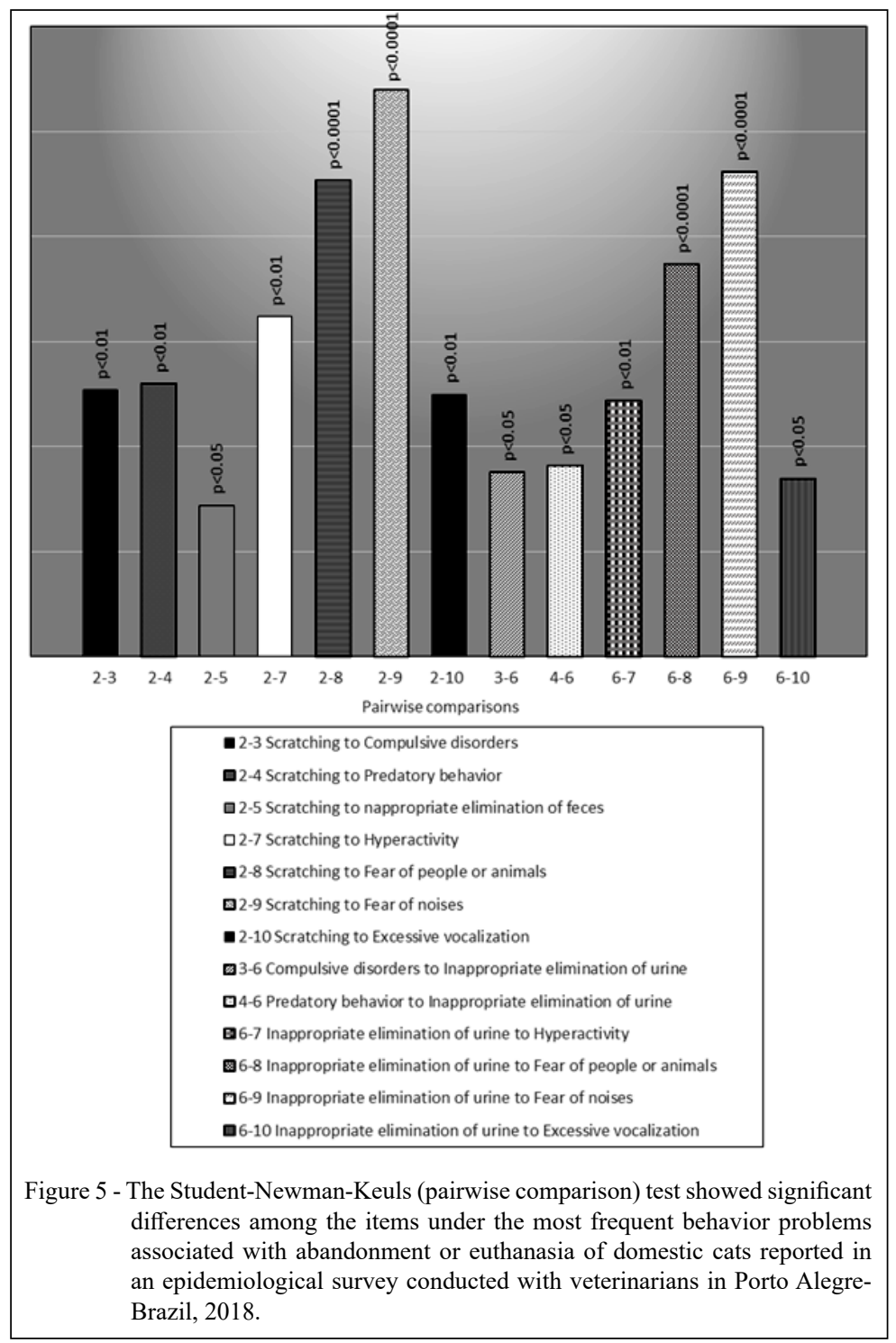

their animals; this would enable early identification and, possibly, treatment of these problems before abandonment (SCARLETT et al., 2002).

With respect to the main targets of feline aggression, the participants cited other cats $(40.4 \%)$ as the most common targets, followed by family members $(36.4 \%)$ and unfamiliar people $(11.1 \%)$. The KruskalWallis test showed significant differences among items $(\mathrm{P}<0.0001)$. On pairwise comparison, animals from other species and unfamiliar people showed no significant difference $(\mathrm{P}=0.6)$ as targets. Other cats showed significant differences between animals from other species and unfamiliar people $(\mathrm{P}<0.0001)$ as targets. Family members showed significant differences compared to other cats and unfamiliar people $(\mathrm{P}<0.05)$ as targets. Animals from other species showed significant differences compared to family members $(\mathrm{P}<0.01)$ as targets. These results agreed with those reported by AMAT et al. (2009) which state that $64.0 \%$ of cases of aggression involved conflicts between cats. Furthermore, in the study by DANTAS et al. (2009), cats and other species were both reported to be the most frequent targets of aggression (21.7\%). However, FATJÓ et al. (2006) reported that aggression towards people was higher than towards other cats; these results are similar to those obtained by MARITI et al. (2017), in which the most common targets were reported to be family members $(24.1 \%)$. Results of this 
study suggested that many cats live under social stress (DANTAS et al., 2009). Since a large number of cats living in the same house can contribute to an increase in their aggressiveness (AMAT et al., 2009), it is important to ensure that the environment where the animals live allowed them to exhibit their natural coping strategies, such as running away and hiding in situations of stress and social conflict (HORWITZ \& MILLS, 2009).

In this study, the preferred treatment for feline aggression was behavior modification. Medication resulted in significant differences compared to sterilization and behavior modification $(\mathrm{P}<0.0001)$. Sterilization was the most preferred choice for the treatment of inappropriate elimination, according to the responding veterinarians. Results regarding the best choice for the treatment of feline aggressive agree with those obtained by DANTAS et al. (2009) but differ from those obtained by FATJÓ et al. (2006), which showed that sterilization was the most frequently selected treatment method. Concerning the treatment of inappropriate elimination, FATJÓ et al. (2006) also reported castration to be an efficient method for correcting behavioral problems in cats; however, according to the research conducted by DANTAS et al. (2009), behavior modification was the main choice. These findings are consistent with the fact that castration has an estimated success rate of $90.0 \%$ for correcting urine marking in male cats if the behavioral motivation is sexual (RODAN \& HEATH, 2016). Research conducted by PAZ et al. (2017) showed that if cats are castrated before puberty, the chances of them developing inappropriate elimination decrease by up to $57.0 \%$.

\section{CONCLUSION}

According to the present study a large number of veterinary practitioners has been consulted on behavioral problems, highlighting the importance of these professionals in increasing the knowledge about ethology. It is essential that a veterinarian understands the normal behavior of a domestic cat and is able to determine the most appropriate methods of ethological management and environmental enrichment for the control and treatment of undesirable behaviors. Proper identification and management of behavioral disorders of domestic cats can possibly prevent their abandonment.

\section{DECLARATION OF CONFLICT OF INTERESTS}

The authors declare no conflict of interest. The founding sponsors had no role in the design of the study; in the collection, analyses, or interpretation of data; in the writing of the manuscript, and in the decision to publish the results.

\section{AUTHORS' CONTRIBUTIONS}

All authors contributed equally for the conception and writing of the manuscript. All authors critically revised the manuscript and approved of the final version.

\section{BIOETHICS AND BIOSSECURITY COMMITTEE APPROVAL}

This research project was submitted and approved by the research ethics committee of the University Severino Sombra.

\section{REFERENCES}

AMAT, M. et al. Potential risk factors associated with feline behaviour problems. Applied Animal Behaviour Science, v.121, p.134-139, 2009. Available from: <https://doi.org/10.1016/j. applanim.2009.09.012>. Accessed: Nov. 18, 2018. doi: 10.1016/j. applanim.2009.09.012.

DANTAS, L. M. S. et al. Epidemiology of Domestic Cat Behavioral and Welfare Issues: a survey of Brazilian referral animal hospitals in 2009. International Journal of Applied Research in Veterinary Medicine, v.7, n.3, p.130-137, 2009. Available from: <http://jarvm.com/articles/Vol7Iss3/Souza $\% 20$ 130-137.pdf>. Accessed: Jul. 25, 2018.

FATJÓ, J. et al. The epidemiology of behavioral problems in dogs and cats: a survey of veterinary practitioners. Animal Welfare, v.15, p.179-185, 2006. Available from: <https://www.researchgate. net/publication/242325208_The_epidemiology_of_behavioural_ problems_in_dogs_and_cats_A_survey_of_veterinary_practitioners $>$. Accessed: Jul. 25, 2018.

GENARO, G. Aplicação de conceitos básicos em etiologia na clínica médica veterinária felina. Revista de Educação Continuada em Medicina Veterinária e Zootecnia do CR MVSP, São Paulo, v.11, n.1, p.32-37, 2013. Available from: <https:// wp.ufpel.edu.br/felinamente/files/2017/03/Comportamentofelino-1.pdf $>$. Accessed: Nov. 25, 2018.

HORWITZ, D. F.; MILLS, D. S. (Ed.) BSAVA Manual of Canine and Feline Behavioural Medicine. 2. ed. Gloucester: British Small Animal Veterinary Association, 2009.

MARITI, C. et al. The perception of cat stress by Italian owners. Journal of Veterinary Behavior, v.20, p.74-81, 2017. Available from: <https://www.sciencedirect.com/ science/article/pii/S1558787817300874>. Accessed: Dec. 11, 2018. doi: $10.1016 /$ j.jveb.2017.04.002.

MENGOLI, M. et al. Scratching behaviour and its features: a questionnaire-based study in an Italian sample of domestic cats. Journal of Feline Medicine and Surgery. v.15, n.10, p.886-892, 2013. Available from: <http://jfm.sagepub. com/content/15/10/886>. Accessed: Dec. 12, 2018. doi: $10.1177 / 1098612 X 13481468$.

PAZ, J. E. G. et al. Fatores associados a distúrbios de comportamento em gatos. Pesquisa Veterinária Brasileira, v.37, n.11, p.1336-1340, 2017. Available from: <http://www.scielo.br/ 
pdf/pvb/v37n11/1678-5150-pvb-37-11-01336.pdf>. Accessed: Nov. 18, 2018. doi: 10.1590/S0100-736X2017001100023.

RAMOS, D.; MILLS, D. S. Human directed aggression in Brazilian domestic cats: owner reported prevalence, contexts and risk factors. Journal of Feline Medicine and Surgery, v.11, p.835-841, 2009. Available from: <https://journals.sagepub.com/ doi/10.1016/j.jfms.2009.04.006>. Accessed: Dec. 15, 2018. doi: 10.1016/j.jfms.2009.04.006.

RODAN, I.; HEATH, S. (Eds) Feline Behavioral Health and Welfare. Saint Louis: Elsevier, 2016.

SALMAN, M. D. et al. Behavioral Reasons for Relinquishment of Dogs and Cats to 12 Shelters. Journal of Applied Animal Welfare Science, v.3, n.2, p.93-106, 2000. Available from: $<$ https://www. researchgate.net/publication/45251733_Behavioral_Reasons_for Relinquishment_of_Dogs_and_Cats_to_12_Shelters $>$. Accessed: Nov. 26, 2018. doi: $10.1207 / \mathrm{S} 15327604 J A W S 0302 \_2$.
SCARLETT, J. M. et al. The role of veterinary practitioners in reducing dog and cat relinquishments and euthanasias. Journal of the American Veterinary Medical Association. v.220, n.3, p.306-31, 2002. Available from: <https://avmajournals.avma.org/ doi/10.2460/javma.2002.220.306>. Accessed: Nov. 26, 2018. doi: 10.2460/javma.2002.220.306

VOGT, A. H. et al. AAFP-AAHA Feline Life Stage Guidelines. Journal of Feline Medicine and Surgery, v.12, n.1, p.4354, 2010. Available from: <https://journals.sagepub.com/ doi/10.1016/j.jfms.2009.12.006>. Accessed: Nov. 18, 2018. doi: 10.1016/j.jfms.2009.12.006.

WILSON, C. et al. Owner observations regarding cat scratching behavior: an internet-based survey. Journal of Feline Medicine and Surgery, v.18, n.10, p.791-797, 2015. Available from: $<$ https://journals.sagepub.com/doi/abs/10.1177/1098612X1 5594414? journalCode $=\mathrm{jfm}>$. Accessed: Dec. 12, 2018. doi: $10.1177 / 1098612 X 15594414$ 